\title{
Family practitioners and sexually transmitted diseases
}

\author{
MARC STEBEN, MD, CCFP
}

\begin{abstract}
M Steben. Family practitioners and sexually transmitted diseases. Can $J$ Infect Dis 1991;2(Suppl A):27A-30A. The family practitioner's role has traditionally been to maintain health with periodic examinations and to restore health in times of illness and injuries. Today, family practitioners are expected to play a more proactive role by assessing unexpressed patient needs. This new approach focuses on global knowledge of the patient, including lifestyle and workplace history. When assessing sexually transmitted diseases (STDs) in particular, it is important for the family practitioner to recognize the association of morality issues and to counsel without being judgemental. Primary prevention of STDs is aimed at reducing or eliminating risks before exposure occurs, and includes counselling on safe sex, condom use, substance abuse, needle/syringe use, and consideration of hepatitis B immunization and universal screening of pregnant women for hepatitis B surface antigen. Secondary prevention refers to the recognition and elimination (if possible) of an STD after exposure and includes early disease detection, adequate STD treatments, screening, human immunodeficiency virus testing with pre- and post test counselling, epidemiological treatment of patient contacts, and hepatitis B prophylaxis by passive or active immunization. Tertiary prevention is aimed at limiting disease progression or reversing damage, but such measures are usually quite expensive and of limited value. Assessment of risks for hepatitis B virus infection should include lifestyle indices such as sexual preference, sexual expression, number of partners and alcohol/drug consumption. Prostitutes, street youth and sexually abused individuals should be considered at high risk for hepatitis B virus infection. Counselling about hepatitis B virus infection involves risk evaluation, patient education, evaluation of immune status to hepatitis $B$ virus and discussions about vaccine needs and availability.
\end{abstract}

Key Words: Counselling. Family practitioners, Prevention, Sexually transmitled diseases

\section{Le médecin de famille et les maladies transmissibles sexuellemen†}

RESUME: Le rôle traditionnel du médecin de famille consistait à maintenir la santé de ses clients par des examens périodiques, et à assurer leur rétablissement en cas de maladies ou de traumatismes. Mais aujourd'hui, le médecin de famille doit assumer un rôle plus actif et évaluer les besoins que certains patients n'expriment pas ou ne reconnaissent pas. Cette nouvelle approche est axée sur la connaissance globale du patierit - modes de vie et activités professionnelles y compris. Quand il examine un patient à la recherche de maladies transmissibles sexuellement (MTS) en particulier, il est important que le médecin de famille reconnaisse qu'il entre dans le domaine des questions morales: il se doit de conseiller sans juger. Lat

Clinique Médicale de l'ouest; Lecturer, Fuculty of Medicine, Université de Montréal: and Department of Sexology. Université du Québec à Montréal, Montréal, Québec

Correspondence and reprints: Dr M Steben, Clinique Médicale de l'ouest, 4647, avenue Verdun, Verdun. Québec H4G 1 M7 
prevention des MTS doit viser avant tout à rẻduire ou à éliminer les risques avant même l'exposition. Elle inclut l'éducation sur la sexualité sécuritaire, l'usage des préservatifs, l'abus des drogues, l'utilisation des aiguilles et seringues, la vaccination anti-hépatite $\mathrm{B}$ (HB) et le dépistage universel des femmes enceintes à la recherche de l'antigène de surface de l'hêpatite $\mathrm{B}$ (HBsAg). La prévention secondaire consiste à reconnaître une MTS éventuelle après l'exposition et à l'êliminer (si possible); elle inclut le diagnostic précoce de l'infection, le traitement adéquat, le dépistage, le test sérologique du virus de l'immunodéficience humaine (VIH) accompagné d'un counselling pré-test et post-test approprié, le traitement ćpidémiologique des contacts, et les stratégies prophylactiques anti-HB utilisant la vaccination passive et/ou active. La prévention tertiaire vise à limiter l'évolution de la maladie ou à inverser les dommages. Ces dernières mesures sont habituellement assez dispendieuses et de valeur limitée. L'évaluation des risques d’infection à VHB devrait tenir compte des indices de mode de vie tels que la préférence sexuelle, l'expression sexuelle, le nombre de partenaires et la consommation d'alcool et/ou de drogues. Les prostitué(e)s, les jeunes de la rue et les personnes ayant subi des sévices sexuels devraient être considérês comme appartenant au groupe à haıı risque d'infection à VHB. L'orientation relative à l'infection à VHB comprend l'évaluation des risques, l'éducation du patient, l'évaluation du statut immunitaire, des discussions portant sur la nécessitê d'une vaccination éventuelle ainsi que son accessibilitê.

W E ARE CURRENTLY IN THE MIDST OF A WORLD wide epidemic of sexually transmitted diseases (STDs). Not having been able to resolve the gonorrhea and chlamydia problems, we are entering the era of viral STDs. For most viral STDs there is chronicity, no curative treatment and the threat of oncogenicity. Family practitioners have been vital players in major breakthroughs in preventive medicine. For example, without help from family practitioners, such significant declines in the prevalences of tuberculosis, cervical cancer and cardiovascular disease could not have been achieved. Similarly, family practitioners should be regarded as key members of the health professional team in the fight against STDs.

Family practitioners are involved in many areas of the Canadian health care system, from clinic and hospital settings to, more recently, the workplace and school. Their roles have centred on maintaining health by timely periodic examinations and screening for disease before complications, and on restoring health in times of illness and injuries. Family practitioners' roles today are changing, however, as they are expected to be proactive, especially in the field of STDs. The new approach is centred on acquiring a global knowledge of the patient, which includes lifestyle and workplace issues. In addition, family practitioners must attempt to assess the unexpressed needs of patients (1).

STDs remain a puzzle for many general practitioners. General practitioners have ranked diagnosing STDs fifth on a list of 24 primary care and health care problems, according to a study in Quebec by Leclère et al (2). Since STDs are linked to morality issues and taboos, it is of the utmost importance that family practitioners recognize the implications of their own personal values clashing with those of some STD patients. Family practitioners should attempt to eliminate or reduce patient risks related to sex and drugs with education and counselling, not with judgemental remarks.

\section{PRIMARY PREVENTION}

Primary prevention is achieved by reducing or eliminating exposure or by heightening defence mechanisms against the agent of disease. Family practitioners are responsible for 'safe sex' counselling and should know the appropriate colloquial sexual expressions. They should teach patients how to recognize the risks of STDs in sexual partners and discuss how to negotiate protection. Safe sex counselling should include a thorough questionnaire about sexual preference, sexual expressions, numbers of partners and, when necessary or appropriate, commercial sex and sexual abuse (3). Street youth and persons without known addresses should be identified as they are a particularly vulnerable group. Use of condoms should be discussed with respect to the best type (eg, latex) or brand to buy, how to prevent breakage or, if the patient does not use them, why not. Substance abuse should be discussed as it tends to decrease preventive behaviour. Furthermore, referral for detoxification and/or education about access to clean injection material dramatically decreases human immunodeficiency virus (HIV) seroconversion in intravenous drug users (4).

Hepatitis $B$ vaccination is very important since it achieves over $95 \%$ protection in hepatitis B virus-exposed subjects (5). Over one-half of acute hepatitis $B$ virus infections are sexually transmitted (about 25\% heterosexually, 33\% homosexually). Vaccination of sexually active persons is 
persons is associated with a beneficial cost/benefit ratio, even at today's cost (6). Universal screening of pregnant women for hepatitis B surface antigen and active and passive vaccination of their offspring (recommended by the National Advisory Committee on Immunization) are also of great public health benefit. Family practitioners play an important role in educating and implementing universal precautions in health care settings, to prevent infections due not only to human immunodeficiency virus (HIV) (fewer than 1\%), but also those due to hepatitis B virus (approximately $30 \%$ ) and others (7).

\section{SECONDARY PREVENTION}

Secondary prevention involves elimination of the agent of disease after exposure but before complications. Early disease recognition by both patient and physician is very important since many STDs manifest clinically for only brief periods before symptoms disappear despite persistence of the disease agent. Adequate STD treatment is also important since exposure to inadequate dosages may increase the risk of resistance against antimicrobials and increase subclinical disease in patients. Consequently, these patients may continue spreading the inadequately treated STDs to former or new sexual partners in the false belief that they have been cured.

It is also advisable to screen patients in whom infection is suspected and to treat "epidemiologically' contacts of proven index cases, even without confirmation test results (3). HIV testing with pre- and post test counselling is also important not only to discover HIV carriers but also to communicate risk reduction messages (3). Hepatitis B virus post exposure prophylaxis for sexual, nonsexual and parenteral contact is feasible with passive and/or active vaccination (8). Post exposure prophylaxis is more effective if given soon after contact. Appropriate management of contacts should be outlined in a policy for which adequate education would be required.

\section{TERTIARY PREVENTION}

Tertiary prevention is aimed at limiting disease progression or reversing damage due to disease. A strategy such as in vitro fertilization for infertility arising from chlamydtal salpingitis is quite expensive and of limited efficacy: fewer than $10 \%$ of in vitro fertilization cycles produce a live birth (9); it could thus cost more than $\$ 60,000$ per live birth (based on actualized costs from American studies [10]). Zidovudine (AZT), on the other hand, reduces the evolution of HIV infection but costs from $\$ 2000$ to $\$ 8000$ per year of treatment and is in no way curative. Acyclovir can prevent resurgence of herpes simplex virus infection but can cost from $\$ 30$ per episodic treatment to $\$ 1200$ a year for suppressive therapy. Interferon alpha-2b has been shown to stop hepatitis B virus replication in hepatic cells of chronic carriers and can cost over $\$ 12,000$ per patient treated. Compared to primary prevention, tertiary prevention is not very cost effective: treatment of one carrier of hepatitis B virus with interferon alpha- $2 \mathrm{~b}$ would cost the same as administering hepatitis $B$ virus vaccinations to a group of 120 people.

\section{COUNSELLING ABOUT HEPATITIS B VIRUS}

Identification of STD risk is frequently not considered in a medical history. Hepatitis B virus risk can be determined with good workplace and STD risks assessment and social indices reconnaissance. Since the general population and the average patient know little about hepatitis $B$ virus compared to HIV or syphilis, education about hepatitis B virus infection is crucial (11). Educational material about hepatitis B virus is available through the Canadian Liver Foundation, various provincial health agencies and drug companies. Patient consent for hepatitis $B$ virus vaccination must be based on prior discussions with a family practitioner on the benefits, potential side effects and limitations of the vaccine. In addition, prevaccination evaluation of immune status by appropriate serological testing may be warranted for individuals suspected of exposure. Patients with limited financial resources, for whom accessibility might be a concern, should be informed of the availability of public health vaccination pro. grams.

Since the target populations and costs for hepatitis $\mathrm{B}$ virus immunization would be similar to those for HIV immunization, hepatitis B virus immunization represents a unique public health opportunity for in-field practice before an HIV vaccine becomes available (6).

In conclusion, family practitioners are obligated to take a proactive role in the treatment and prevention of STDs. Procrastination by family practitioners and public health authorities in implementing hepatitis B virus immunization programs will prove costly to the health care system and patients.

\section{REFERENCES}

1. Blondeau F. L'anamnèse centrée sur le malade. Can Fam Physician 1990;36:1509-13.

2. Leclère $H$, Beaulieu MD, Bordage $G$, et al. Why are clinical problems difficult? General practitioners opinions concerning 24 clinical problems. Can Med Assoc J 1990; 143:1305-15.

3. 1989 Sexually transmitted diseases. Treatment 
guidelines. MMWR 1989;38(S8):vii.

4. Gruer L. Opening session. The First National Workshop on HIV Infection and Injection Drug Use: Strategies for Prevention, Montreal, 1990.

5. Szmuness $W$, et al. A controlled clinical trial of the efficacy of the hepatitis B vaccine (HEPTAVAX B): A final report. Hepatology 1981;1:377.

6. Cates W. Viral STD; What can we do besides educate? STD-88 National Conference 'Partnership for Prevention', YEAR:23-6.

7. Lague J. Les travailleurs de la santé. In: Le SIDA, Un Nouveau Défi Médical. Montréal: Association des médecins de langue française du Canada. 1990:239.
8. Canadian Immunization Guide. Can Med Assoc J 1989; 141:227-8.

9. Medical Research International. The fertility society special interest group: In vitro fertilization. Embryo transfer in the United States: 1985 and 1986 results from national IVF/ET registry. Fertil Steril 1988;49:212.

10. Glinca S, Cooper MS. Analysis of the costs of infertility treatment. Am J Public Health 1986;72:1018-9.

11. Steben M, Pelletier J, Fluet M, et al. Attitudes and perceptions about certain aspects of STD. International Society for STD Research Annual Meeting, Atlanta, Georgia, 1987. 


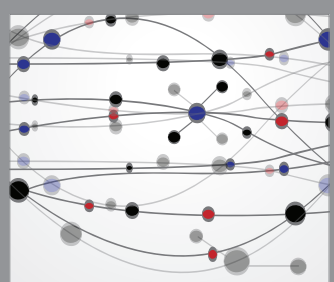

The Scientific World Journal
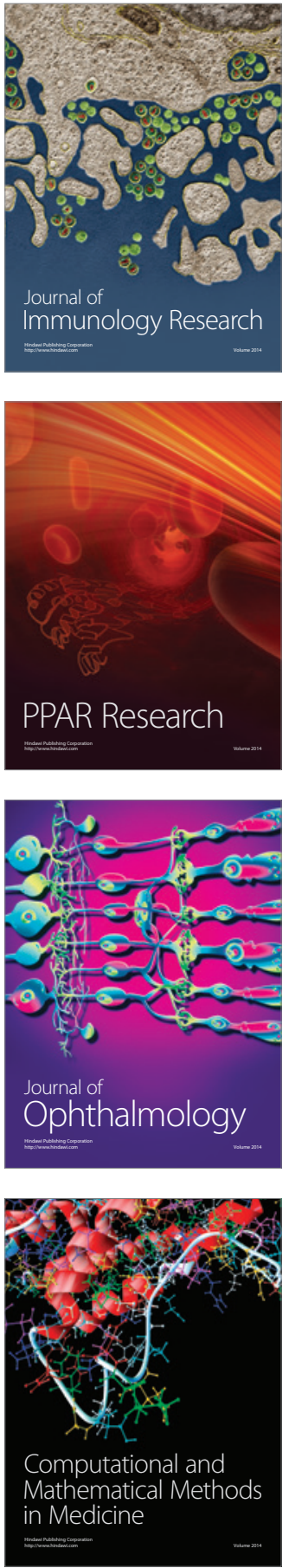

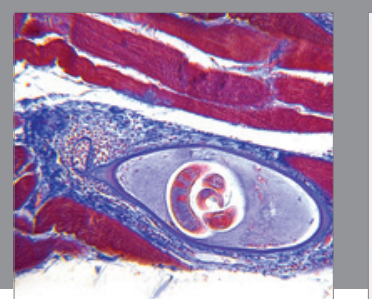

Gastroenterology Research and Practice

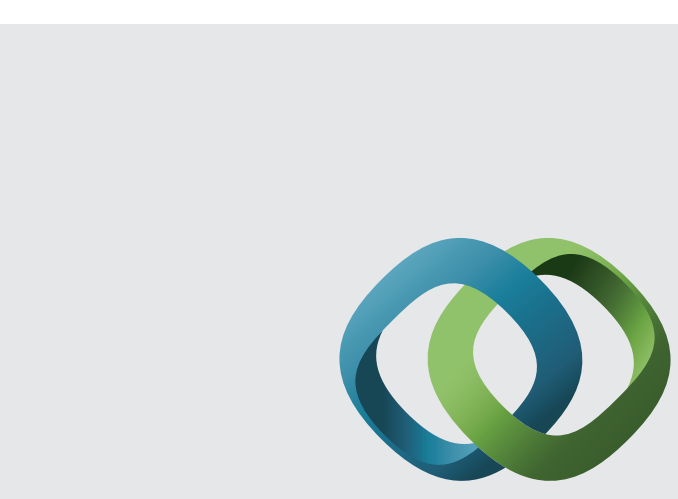

\section{Hindawi}

Submit your manuscripts at

http://www.hindawi.com
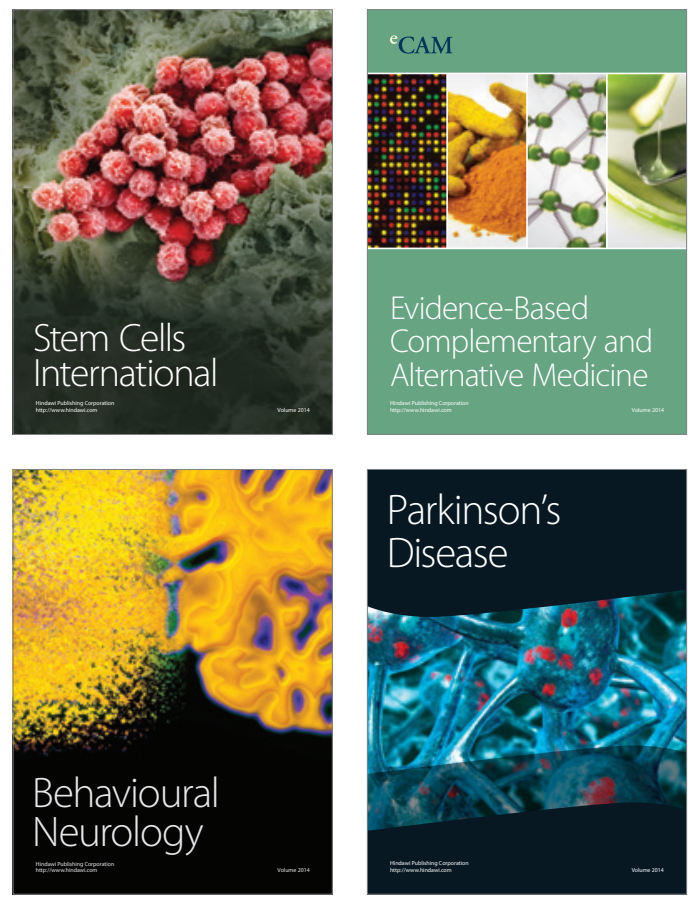
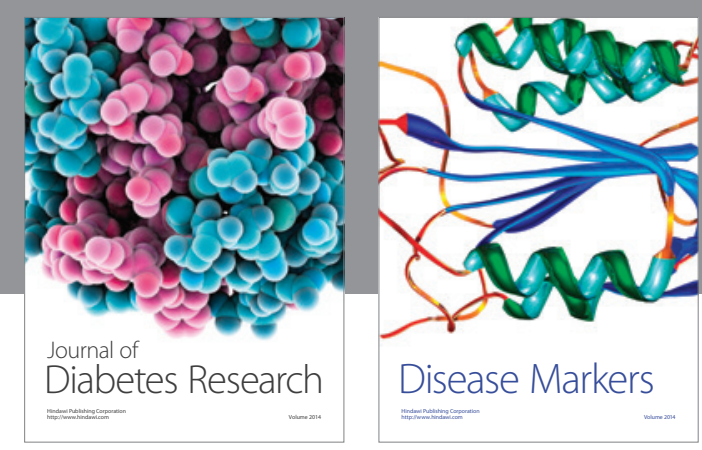

Disease Markers
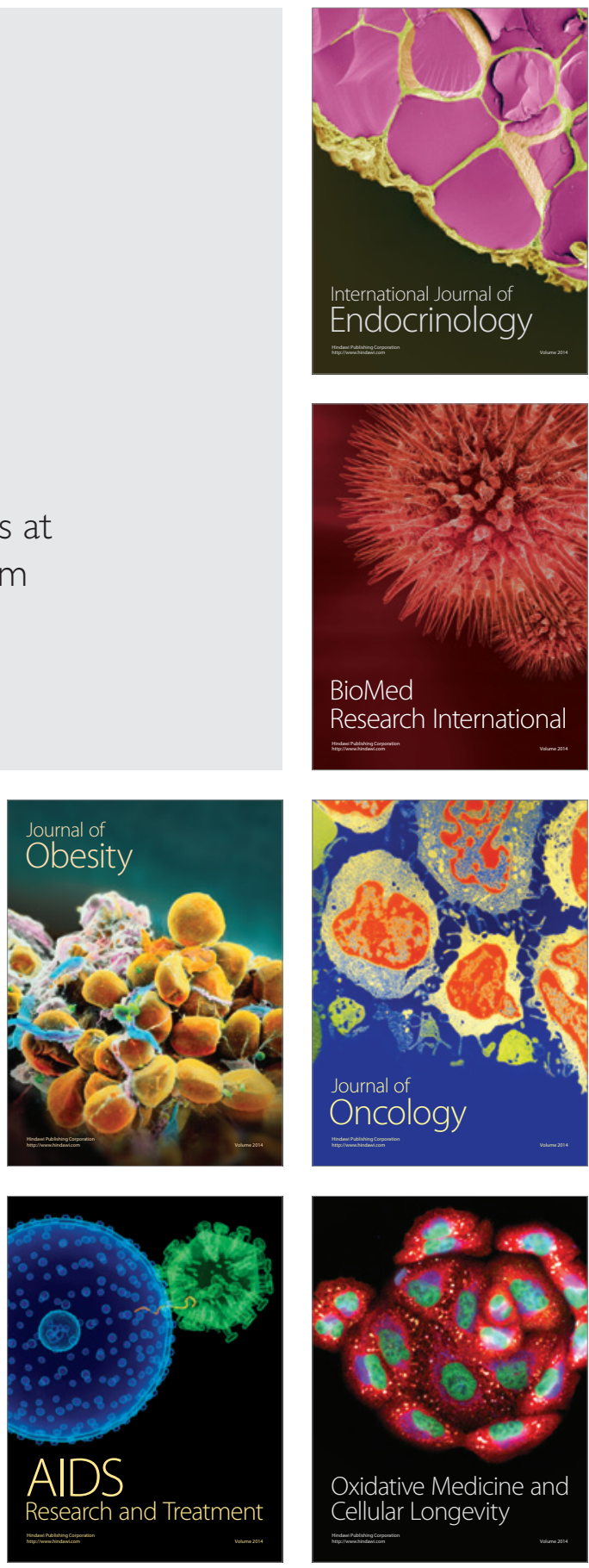